\title{
UPAYA MENINGKATKAN KEMAMPUAN BERPIKIR KRITIS SISWA MELALUI METODE PEMBELAJARAN THINK-PAIR-SHARE (TPS) MATERI HUBUNGAN STRUKTURAL DAN FUNGSIONAL PEMERINTAH PUSAT DAN DAERAH Pada Siswa Kelas X IPS 1 Di SMA Negeri 6 Surakarta Tahun Ajaran 2017 / 2018
}

\author{
Tri Budiarsih \\ Siti Supeni \\ Progdi PPKn FKIP UNISRI Surakarta
}

Tujuan penelitian ini adalah untuk mengetahui pelaksanaan model Think-Pair-Share (TPS) dalam pembelajaran PPKn materi hubungan struktural dan fungsional pemerintah pusat dan daerah pada siswa kelas X IPS 1 di SMA Negeri 6 Surakarta tahun ajaran 2017 / 2018. Untuk meningkatkan kemampuan berpikir kritis siswa melalui metode Think-Pair-Share (TPS) dalam pembelajaran PPKn materi hubungan struktural dan fungsional pemerintah pusat dan daerah pada siswa kelas X IPS 1 di SMA Negeri 6 Surakarta tahun ajaran 2017 / 2018.

Penelitian ini dilaksanakan di SMA Negeri 6 Surakarta. Subjek dalam penelitian ini adalah siswa kelas X IPS 1 yang berjumlah 26 siswa. Penelitian ini adalah Penelitian Tindakan Kelas (PTK) yang dilaksanakan dalam 2 siklus, setiap siklus terdiri dari 4 tahap yaitu perencanaan, pelaksanaan tindakan, observasi, refleksi. Teknik analisis data yang digunakan adalah deskriptif kritis komparatif. Teknik pengumpulan data yang digunakan yaitu observasi, angket, tes, wawancara dan dokumentasi.

Berdasarkan hasil tindakan siklus I diperoleh ketuntasan belajar sebesar 100\% dengan nilai rata-rata 84,538 dan hasil tindakan siklus II diperoleh ketuntasan belajar sebesar $100 \%$ dengan nilai rata-rata 93,5. Berdasarkan penelitian tersebut dapat diambil kesimpulan bahwa penerapan metode pembelajaran Think Pair Share (TPS) dapat meningkatkan kemampuan berfikir kritis siswa mata pelajaran PPKn materi hubungan struktural dan fungsional pemerintah pusat dan daerah pada siswa kelas X IPS 1.

Kata kunci : Berpikir Kritis, Metode Think Pair Share (TPS). 


\section{PENDAHULUAN}

Berdasarkan pengamatan yang ada di lapangan, yaitu hasil analisis dari observasi yang telah dilakukan pada pembelajaran PPKn kelas X IPS 1 di SMA Negeri 6 Surakarta menunjukkan masih rendahnya tingkat berpikir kritis siswa dalam proses pembelajaran PPKn. Hal ini terlihat, siswa kurang aktif, keegoisan masih ada, kurang komunikatif, kurang adanya percaya diri, tidak mampu merumuskan pokok-pokok permasalahan, tidak mampu berpendapat sesuai dengan materi pelajaran, dan tidak dapat menyelesaikan soal dengan baik dan benar.

Selain itu model pembelajaran yang digunakan masih bersifat monoton belum bervariasi yaitu ketika guru melaksanakan proses kegiatan belajar mengajar di kelas masih sering menggunakan model ceramah. Proses pembelajaran juga masih menerapkan pembelajaran teacher centered dimana siswa hanya memperhatikan penjelasan guru, padahal seharusnya sudah menerapkan student center learning, sesuai kurikulum K13. Selain hal di atas, masalah lain yang muncul di kelas tersebut yaitu kegiatan belajar lebih ditandai dengan hafalan.

Dalam pelaksanaan pembelajaran PPKn di kelas, siswa kurang belajar lebih aktif, kreatif dan tidak mandiri. Apabila hal tersebut berjalan terus menerus, maka dapat mengakibatkan daya berfikir siswa menjadi rendah yang membuat siswa tidak mampu untuk mengembangkan dirinya untuk lebih kritis dalam berpikir.

Terkait dengan hal di atas, berpikir kritis dapat dikembangkan melalui pembelajaran PPKn karena PPKn sendiri memiliki karakteristik yang salah satunya yaitu melatih siswa berpikir kritis. PPKn merupakan salah satu mata pelajaran yang memiliki peranan untuk meningkatkan kemampuan berpikir kritis dan kreatif. Berpikir kritis diterapkan siswa untuk belajar memecahkan masalah secara tepat dan memberi gambaran solusi yang tepat dan mendasar. Dalam hal ini tugas guru sebagai seorang pendidik diharapkan dapat memberikan rangsangan untuk membuat siswa berpikir kritis. Atau dapat juga dengan memberi kebebasan kepada siswa lebih mandiri dan mampu menyelesaikan masalah yang dihadapi dan disesuaikan dengan materi pelajaran.

Pemilihan metode pembelajaran harus disesuaikan dengan tujuan pembelajaran, bervariasi, inovatif dan dapat menumbuhkan peran aktif siswa agar proses pembelajaran yang berlangsung lebih menarik dan hidup. Siswa juga lebih semangat dan antusias untuk mengikuti pelajaran, dan hal tersebut juga dapat memancing siswa untuk mengembangkan dirinya agar berfikir kritis.

Usaha yang ditempuh penulis adalah dengan menerapkan model pembelajaran tipe Think Pair Share dalam proses pembelajaran dengan mengunakan PTK (Penelitian Tindakan Kelas). Alasan penggunaan model pembelajaran tipe Think Pair Share dalam penelitian ini adalah disesuaikan dengan perkembangan karakteristik siswa SMA kelas $\mathrm{X}$ yaitu tahap perkembangan operasional konkret dan untuk menarik semua siswa agar lebih berpikir kritis dan dapat berpartisipasi dalam proses atau kegiatan pembelajaran PPKn yang sedang berlangsung di kelas.

Penggunaan metode tersebut juga disesuaikan dengan karakteristik siswa kelas X SMA yang memiliki rasa ingin tahu yang tinggi dan suka berkelompok. Dengan model pembelajaran tipe think pair share ini semua siswa dapat terlibat untuk aktif dalam pembelajaran, tidak hanya siswa yang pandai saja yang dominan. Karena di dalam model tipe think pair share terdiri dari tiga tahap kegiatan siswa yang menekankan pada apa yang dikerjakan siswa pada setiap tahapannya, yaitu berfikir (think), siswa berpasangan (pair), siswa berbagi (share).

Mengenai peningkatan kemampuan berpikir kritis siswa dalam pembelajaran PPKn, instrumen yang digunakan untuk mengukur kemampuan berpikir kritis yaitu berupa soal. Penelitian tersebut dapat diketahui dengan melihat hasil nilai yang diperoleh siswa dari mengerjakan soal menunjukkan pada setiap siklusnya sebagian besar siswa mengalami 
peningkatan. Hal itu berarti bahwa kemampuan berpikir kritis siswa meningkat.

Oleh karena itu melalui Penelitian Tindakan Kelas, penulis memilih judul mengenai "Upaya Meningkatkan Kemampuan Berpikir Kritis Siswa Melalui Metode Pembelajaran Think-Pair-Share (TPS) Materi Hubungan Struktural Dan Fungsional Pemerintah Pusat dan Daerah Pada Siswa Kelas X IPS 1 Di SMA Negeri 6 Surakarta Tahun Ajaran 2017 / 2018.”, sehingga keterampilan berpikir kritis siswa dapat mengalami peningkatan.

Tujuan penelitian ini adalah untuk mengetahui pelaksanaan model Think-PairShare (TPS) dalam pembelajaran PPKn materi hubungan struktural dan fungsional pemerintah pusat dan daerah pada siswa kelas X IPS 1 di SMA Negeri 6 Surakarta tahun ajaran 2017/2018. Untuk meningkatkan kemampuan berpikir kritis siswa melalui metode Think-Pair-Share (TPS) dalam pembelajaran PPKn materi hubungan struktural dan fungsional pemerintah pusat dan daerah pada siswa kelas X IPS 1 di SMA Negeri 6 Surakarta tahun ajaran 2017/ 2018.

\section{KAJIAN PUSTAKA}

\section{Kemampuan Berpikir Kritis}

\section{a. Pengertian Berpikir Kritis}

Menurut pendapat lain yang dikemukakan Jhonson dalam Eti Nurhayati, (2011: 67) yang mengartikan berpikir kritis merupakan proses mental yang terorganisasi dengan baik dan berperan dalam proses mengambil keputusan untuk memecahkan masalah dengan menganalisis dan menginterpretasi data dalam kegiatan inkuiri ilmiah. Sedang menurut pandangan dari Ennis mendefinisikan berpikir kritis (Eti Nurhayati, 2011: 67) menjelaskan bahwa berpikir kritis adalah berpikir reflektif yang berfokus pada pola pengambilan keputusan tentang apa yang harus diyakini dan harus dilakukan. Definisi lain yang dikemukakan oleh Fahruddin Faiz (2012: 3) bahwa kemampuan berpikir kritis adalah merupakan kemampuan yang sangat penting untuk kehidupan, pekerjaan dan berfungsi efektif dalam semua aspek kehidupan. Berdasarkan beberapa pengertian di atas, maka dapat disimpulkan bahwa berpikir kritis adalah cara berpikir yang masuk akal atau berdasarkan nalar berupa kegiatan mengorganisasi, menganalisis, dan mengevaluasi informasi dengan fokus untuk menentukan hasil dari apa yang dilakukan.

\section{b. Kemampuan Berpikir}

Vincent Ruggiero dalam Chaedar Alwasilah, (2006: 187) mengartikan berpikir sebagai "segala aktivitas mental yang membantu merumuskan atau memecahkan masalah, membuat keputusan, atau memenuhi keinginan untuk memahami; berpikir adalah sebuah pencarian jawaban, sebuah pencapaian makna. Pendapat yang hampir sama dikemukakan oleh Solso dalam Sugihartono,dkk, (2007: 13) yang menyatakan bahwa berpikir merupakan proses yang menghasilkan representasi mental yang baru melalui transformasi informasi yang melibatkan interaksi yang kompleks antara berbagai proses mental seperti penilaian, abstraksi, penalaran, imajinasi dan pemecahan masalah. Selanjutnya, Ngalim Purwanto, (1992: 43) juga mengemukakan bahwa berpikir adalah suatu keaktifan pribadi manusia yang mengakibatkan penemuan yang terarah kepada suatu tujuan. Dari beberapa definisi di atas, maka berfikir adalah suatu kegiatan akal untuk mengolah pengetahuan yang telah diperoleh dan digunakan untuk memecahkan masalah serta memperoleh jawaban yang sesuai dengan logika.

\section{c. Aktivitas dan Ciri-ciri Berpikir Kritis}

Pendapat yang dijabarkan oleh Eti Nurhayati (2011: 69) yaitu ciri-ciri orang yang mampu berpikir kritis adalah: (1) memiliki perangkat pemikiran tertentu yang dipergunakan untuk mendekati gagasannya; (2) memiliki motivasi kuat untuk mencari dan memecahkan masalah; (3) bersikap 
skeptik yakni tidak mudah menerima idea atau gagasan kecuali ia dapat membuktikan kebenarannya. Pendapat di atas yang dirumuskan oleh Fahruddin Faiz, (2012: 3) dalam aktivitas-aktivitas kritis yang dibagi menjadi lima kelompok kemampuan berpikir yaitu sebagai berikut:

1) Mampu merumuskan pokok-pokok permasalahan, meliputi: Mencari jawaban yang jelas dari setiap pertanyaan,

2) Mampu mengungkap fakta yang dibutuhkan dalam menyelesaikan suatu masalah, meliputi: berusaha mengetahui informasi dengan tepat, memakai sumber yang memiliki kredibilitas dan menyebutkannya, memahami tujuan yang asli dan mendasar.

3) Mampu memilih argumen yang logis, relevan dan akurat, meliputi: mencari alasan atau argument, berusaha tetap relevan dengan ide utama, berfikir dan bersikap secara sistematis dan teratur dengan memperhatikan bagian-bagian dari keseluruhan masalah.

4) Mampu mendeteksi bias berdasarkan sudut pandang yang berbeda, meliputi: mencari alternatif jawaban, mengambil sikap ketika ada bukti yang cukup untuk melakukan sesuatu, mencari penjelasan sebanyak mungkin apabila memungkinkan.

5) Mampu menentukan akibat dari suatu pertanyaan yang diambil sebagai suatau keputusan, meliputi: memperhatikan situasi dan kondisi secara keseluruhan, bersikap dan berfikir terbuka.

Berdasarkan uraian indikator-indikator berpikir kritis diatas, maka aspek yang akan digunakan sebagai acuan dalam penelitian ini, adalah:

a. Mampu merumuskan pokokpokok permasalahan.

b. Mampu mengungkapkan fakta untuk menyelesaikan permasalahan.

c. Mampu memilih pendapat yang sesuai dengan kenyataan.

d. Mampu memberikan pendapat dari sudut pandang yang berbeda. e. Mampu menyelesaikan masalah yang timbul dari suatu pernyataan.

\section{d. Tujuan Berpikir Kritis}

Fahruddin Faiz, (2012: 2) mengemukakan bahwa tujuan berpikir kritis sederhana yaitu untuk menjamin, sejauh mungkin, bahwa pemikiran kita valid dan benar. Sedangkan tujuan berpikir kritis yang dikemukakan oleh Supriya, (2009: 144) adalah untuk menilai suatu pemikiran, menaksir nilai bahkan mengevaluasi pelaksanaan atau praktik dari suatu pemikiran dan praktik tersebut. Berdasarkan pendapat di atas, maka dapat disimpulkan bahwa tujuan berpikir kritis adalah untuk menguji mutu pendapat atau ide melalui evaluasi dan praktik yang dapat dipertanggung jawabkan hasilnya.

\section{Metode Pembelajaran TPS}

\section{a. Metode Pembelajaran}

Menurut Hamruni (2012 : 6) metode pembelajaran adalah cara-cara menyajikan bahan pelajaran pada peserta didik untuk tercapainya tujuan pembelajaran yang telah ditetapkan. Menurut Nana Sudjana (2005 : 76) metode pembelajaran adalah cara yang dipergunakan guru dalam mengadakan hubungan dengan siswa pada saat berlangsungnya pengajaran. Jadi metode pembelajaran adalah suatu cara atau strategi yang dilakukan oleh seorang guru dalam menyajikan materi pelajaran agar terjadi proses belajar pada diri siswa untuk mencapai tujuan pembelajaran yang telah ditetapkan.

\section{b. Metode TPS}

Berikut ini akan dijelaskan pengertian, langkah-langkah, serta kelebihan dan kelemahan metode TPS.

1. Pengertian Metode TPS

Menurut Trianto (2011:81)

Strategi Think Pair Share (TPS) atau berpikir berpasangan berbagi adalah merupakan jenis pembelajaran kooperatif yang dirancang untuk mempengaruh pola interaksi siswa. Sedangkan menurut 
Agus Suprijono (2009 : 91) metode Think Pair Share (TPS) seperti namanya "Thinking", pembelajaran ini diawali dengan guru mengajukan pertanyaan atau isu terkait dengan pelajaran untuk dipikirkan oleh peserta didik. Guru memberi kesempatan kepada mereka untuk memikirkan jawabannya. Selanjutnya, "Pairing" Pada tahap ini guru meminta peserta didik berpasang-pasangan untuk berdiskusi. Diharapkan diskusi ini dapat memperdalam makna dari jawaban yang telah dipikirkannya melalui inter subjektif dengan pasangannya. Hasil diskusi inter subjektif di tiap-tiap pasangan hasilnya dibicarakandengan pasangan seluruh kelas. Tahap ini dikenal dengan "Sharing". Berdasarkan semua uraian di atas, maka dapat disimpulkan bahwa metode tipe Think Pair Share merupakan salah satu model pembelajaran yang memberikan kesempatan kepada siswa untuk berpikir, menjawab sesuai dengan tingkat pemikiran siswa atau asumsi siswa sendiri, kemudian berpasangan dan saling membantu dalam kegiatan kelompok untuk memecahkan suatu permasalahan yang ada dalam kelompok.

2. Langkah-langkah Pembelajaran TPS Pendapat yang disampaikan oleh Anita Lie (Isjoni, 2012: 112) Berpikir Berpasangan Berempat (Think Pair Share) pertama kali dikembangkan oleh Frank Lyman dan Spencer Kagan.

Terdapat beberapa tahapan yang dilakukan dalam pelaksanaan Think Pair Share, yang dikemukakan oleh Agus Suprijono (2013: 90) antara lain:

a) "Thinking"(berpikir)

Pada tahap ini pembelajaran diawali dengan guru mengajukan pertanyaan atau isu terkait dengan pelajaran untuk dipikirkan oleh siswa. Guru memberikan kesempatan kepada siswa untuk memikirkan jawabannya.

b) "Pairing" (berpasangan) Pada tahap ini guru meminta peserta didik berpasangpasangan. Guru memberi kesempatan kepada pasangan-pasangan tersebut untuk berdiskusi. Dalam diskusi tersebut diharapkan dapat memperdalam makna dari jawaban yang telah dipikirkannya melalui intersubjektif dengan pasangannya. Hasil diskusi intersubjektif ditiap-tiap pasangan nantinya dibicarakan dengan pasangan lain di seluruh kelas.

c) "Sharing" (berbagi)

Dalam kegiatan ini diharapkan terjadi Tanya jawab yang mendorong pada pengonstruksian pengetahuan secara integrative. Peserta didik dapat menemukan struktur dari pengetahuan yang dipelajari.

Langkah-langkah dalam model pembelajaran think pair share adalah sebagai berikut:

a. Pendahuluan

Disini kegiatan yang dilaksanakan adalah:

1) Guru menjelaskan aturan main dan batasan waktu untuk setiap kegiatan, memotivasi siswa agar terlibat aktif dalam diskusi kelompok. 
2) Guru menjelaskan kompetensi yang harus dicapai oleh siswa.

b. Think

Disini kegiatan yang dilaksanakan adalah:

1) Guru menggali pengetahuan awal siswa melalui kegiatan Tanya jawab.

2) Guru memberikan Lembar Kerja Siswa (LKS) kepada seluruh siswa.

c. Pair

Disini kegiatan yang dilaksanakan adalah:

1) siswa dikelompokkan dengan teman sebangkunya.

2) Siswa berdiskusi dengan pasangannya mengenai jawaban yang telah dikerjakan.

d. Share

Disini kegiatan yang dilaksanakan adalah:

Beberapa dari pasangan kelompok siswa hingga dari jumlah keseluruhan dipanggil secara acak untuk berbagi pendapat kepada seluruh siswa dikelas dengan dipandu oleh guru.

e. Penutup

Disini kegiatan yang dilaksanakan adalah:

Siswa dinilai secara individu dan kelompok.

3. Kelebihan Metode Pembelajaran TPS

Teknik ini memberi siswa kesempatan untuk bekerja sendiri dan bekerja sama dengan orang lain. Keunggulan dari tehnik think pair share adalah optimalisasi partisipasi siswa, yaitu memberi kesempatan delapan kali lebih banyak kepada setiap siswa untuk dikenali dan menunjukkan partisipasi mereka kepada orang lain ( Anita Lie, 2010: 57). Berdasarkan kelebihankelebihan metode TPS diatas dapat disimpulkan bahwa metode TPS memang secara teoritis dapat meningkatkan hasil belajar siswa.

4. Kelemahan Metode Pembelajaran TPS

Menurut Anita Lie (dalam Tukiran, 2011 : 64) kelemahan metode TPS antara lain sebagai berikut :

a) Banyak kelompok yang kurang dimonitor oleh guru.

b) Membutuhkan perhatian khusus dalam penggunaan ruangan kelas.

c) Peralihan dari seluruh kelas ke kelompok kecil dapat menyita waktu.

d) Banyak kelompok yang melapor dan perlu dimonitor.

e) Metode TPS belum banyak diterapkan di sekolah.

f) Untuk mengatasi kelemahan-kelemahan tersebut di atas maka akan dilakukan hal-hal sebagai berikut:

g) Mengusahakan agar semua kelompok dapat dimonitor guru.

h) Mempersiapkan segala sesuatu yang berhubungan dengan teknis pelaksanaan metode TPS, seperti penggunaan ruangan kelas dan pembagian kelompok.

i) Guru harus dapat membuat perencanaan yang seksama sehingga dapat meminimalkan jumlah waktu agar waktu 


$$
\begin{array}{lr}
\text { yang tersedia tidak } \\
\text { terbuang. } \\
\text { j) } \begin{array}{lr}
\text { Mencermati } & \text { dan } \\
\text { membatasi } & \text { kelompok } \\
& \text { yang melapor. }
\end{array}
\end{array}
$$

\section{Pendidikan Pancasila dan Kewarganegaraan (PPKn) di SMA}

\section{a. Hakikat PPKn}

Berdasarkan Depdiknas (2002 : 7), konsep kewarganegaraan merupakan materi yang memfokuskan pada pembentukan diri yang beragam dari segi agama, sosio-kultural, bahasa, usia, dan suku bangsa, untuk menjadi warga negara Indonesia yang cerdas, terampil, dan berkarakter, sesuai dengan yang diamanatkan oleh Pancasila dan UUD 1945. Dapat disimpulkan bahwa hakikat Pendidikan Kewarganegaraan adalah untuk membekali peserta didik dengan pengetahuan dan kemampuan dasar hubungan warga negara Indonesia dan pengembangan karakter warga negara yang sesuai dengan nilai-nilai pancasila dan UUD 1945, karena itu mata pelajaran Pendidikan Kewarganegaraan dilaksanakan di sekolah hingga di perguruan tinggi.

\section{b. Tujuan Pendidikan Kewarganegaraan}

Tujuan mata pelajaran Pendidikan Kewarganegaraan adalah untuk menumbuhkan wawasan dan kesadaran bernegara, sikap serta perilaku yang cinta tanah air dan bersendikan kebudayaan bangsa, wawasan nusantara serta ketahanan nasional dalam diri seseorang (Sumarsono, $2001: 4$ ).

Tujuan mata pelajaran Pendidikan Kewarganegaraan dalam Peraturan Menteri Pendidikan Nasional (Permendiknas) Republik Indonesia Nomor 22 tahun 2006 tentang Standar Isi Pendidikan Kewarganegaraan adalah : a) berpikir secara kritis, rasional, dan kreatif dalam menanggapi isu kewarganegaraan, b) berpartisipasi secara bermutu dan bertanggung jawab, dan bertindak secara cerdas dalam kegiatan bermasyarakat, berbangsa, dan bernegara, serta anti korupsi, c) berkembang secara positif dan demokratis untuk membentuk diri berdasarkan karakter-karakter masyarakat Indonesia agar dapat hidup bersama dengan bangsa-bangsa lainnya, d) berinteraksi dengan bangsa-bangsa lain dalam percaturan dunia secara langsung atau tidak langsung dengan memanfaatkan teknologi informasi dan komunikasi.

\section{c. Ruang Pendidikan Kewarganegaraan}

Lingkup

Menurut Sumarsono (2001 : 6) Pendidikan Kewarganegaraan yang berhasil akan membuahkan sikap mental yang cerdas, penuh rasa tanggung jawab dari peserta didik. Sikap ini disertai perilaku yang a) beriman dan bertakwa kepada Tuhan Yang Maha Esa dan menghayati nilainilai falsafah bangsa, b) berbudi pekerti luhur, berdisiplin dalam bermasyarakat, berbangsa, dan bernegara, c) rasionalis, dinamis, dan sadar akan hak dan kewajiban sebagai warga negara, d) bersifat profesional, yang dijiwai oleh kesadaran bela negara, e) aktif memanfaatkan ilmu pengetahuan dan teknologi serta seni kepentingan kemanusiaan, bangsa dan negara.

\section{d. Paradigma Baru PPKn}

Badan Standar Nasional Pendidikan (BSNP) dalam Fatturohman dan Wuri Wuryandani (2011: 9) Paradigma berarti suatu model atau kerangka berpikir yang digunakan dalam proses pendidikan kewarganegaraan di Indonesia. Sejalan dengan dinamika perkembangan kehidupan berbangsa, bernegara yang ditandai oleh semakin terbukanya persaingan antar bangsa yang semakin berat, maka bangsa Indonesia mulai memasuki era reformasi diberbagai bidang menuju kehidupan masyarakat yang lebih demokratis. 


\section{e. Pembelajaran PPKn di SMA}

Kurikulum yang dipakai pada pendidikan saat ini adalah menggunakan Kurikulum Tiga Belas (K13). Dalam K13 memuat standar kompetensi dan kompetensi dasar, yang digunakan oleh guru untuk mengembangkan pembelajaran kepada siswa dan lebih berpusat kepada siswa, lalu guru hanya sebagai fasilitator. Jadi diharuskan siswa lebih aktif, mandiri, kreatif dan inovatif. Badan Standar Nasional Pendidikan (BSNP) mengembangkan kurikulum berdasarkan prinsip-prinsip berikut.

1) Berpusat pada potensi, perkembangan, kebutuhan, dan kepentingan;

2) Beragam dan terpadu;

3) Tanggap terhadap perkembangan ilmu pengetahuan, teknologi, dan seni peserta didik dan lingkungannya;

4) Relevan dengan kebutuhan kehidupan;

5) Menyeluruh dan berkesinambungan;

6) Belajar sepanjang hayat;

7) Seimbang antara kepentingan nasional dan kepentingan daerah.

\section{METODE}

Penelitian ini dilaksanakan di SMA Negeri 6 Surakarta. Subjek dalam penelitian ini adalah siswa kelas $X$ IPS 1 yang berjumlah 26 siswa. Penelitian ini adalah Penelitian Tindakan Kelas (PTK) yang dilaksanakan dalam 2 siklus, setiap siklus terdiri dari 4 tahap yaitu perencanaan, pelaksanaan tindakan, observasi, refleksi. Teknik analisis data yang digunakan adalah deskriptif kritis komparatif. Teknik pengumpulan data yang digunakan yaitu observasi, angket, tes, wawancara dan dokumentasi.

\section{HASIL}

Peningkatan Kemampuan Berpikir Kritis Siswa dalam Pembelajaran PPKn dengan Menggunakan Model Cooperative Tipe Think Pair Share

Berdasarkan hasil penilaian produk soal berpikir kritis siswa setelah tindakan siklus I, kemampuan brpikir kritis siswa dalam pembelajaran PKn meningkat dibanding dengan penilaian pada saat pratindakan. Peningkatan ini ditunjukkan dengan meningkatnya nilai ketuntasan siswa dari rerata 77,8 dengan prosentase $100 \%$ pada pratindakan menjadi rerata 84,5 dengan prosentase $100 \%$ pada siklus I. Pada siklus II, penilaian kemampuan berpikir kritis siswa meningkat dibanding dengan penilaian pada siklus I. Peningkatan ini ditunjukkan pada penilaian produk siswa yang telah mencapai criteria ketuntasan yaitu sebanyak rerata 93,5 dengan prosentase $100 \%$. Hal ini dirasa sudah cukup memuaskan karena kriteria keberhasilan yang telah ditentukan sudah tercapai yaitu sebanyak $100 \%$ siswa mencapai taraf keberhasilan $100 \%$ dari setiap siklusnya (= rerata 93,5 skor $100 \%$ ).

Peningkatan kemampuan berpikir kritis siswa dalam pembelajaran PKn pada pratindakan, pasca tindakan siklus I, dan pasca tindakan siklus II dapat dilihat pada tabel berikut.

Tabel Perbandingan Kemampuan Berpikir Kritis Siswa pada

Pratindakan, Siklus I dan Siklus II

\begin{tabular}{llccc}
\hline $\begin{array}{c}\text { No } \\
\text { • }\end{array}$ & Nama Siswa & $\begin{array}{c}\text { Pra- } \\
\text { tindaka } \\
\text { n }\end{array}$ & $\begin{array}{c}\text { Siklus } \\
\text { I }\end{array}$ & $\begin{array}{c}\text { Siklu } \\
\text { S II }\end{array}$ \\
\hline 1. & Akhmad V & 79 & 87 & 95 \\
\hline 2. & Aliya A & 77 & 83 & 92 \\
\hline 3. & Angeline E & 76 & 85 & 93 \\
\hline 4. & Ayu R & 76 & 80 & 90 \\
\hline 5. & Charisma D & 79 & 83 & 92 \\
\hline 6. & Clarissa M & 76 & 83 & 93 \\
\hline 7. & Daffa I & 75 & 85 & 93 \\
\hline 8. & Fadhila H & 79 & 83 & 93 \\
\hline 9. & Filipus D & 75 & 85 & 92 \\
\hline 10. & Graciela F & 79 & 85 & 92 \\
\hline 11. & Haleya S & 75 & 82 & 92 \\
\hline 12 & Jahnu P & 79 & 85 & 93 \\
\hline
\end{tabular}




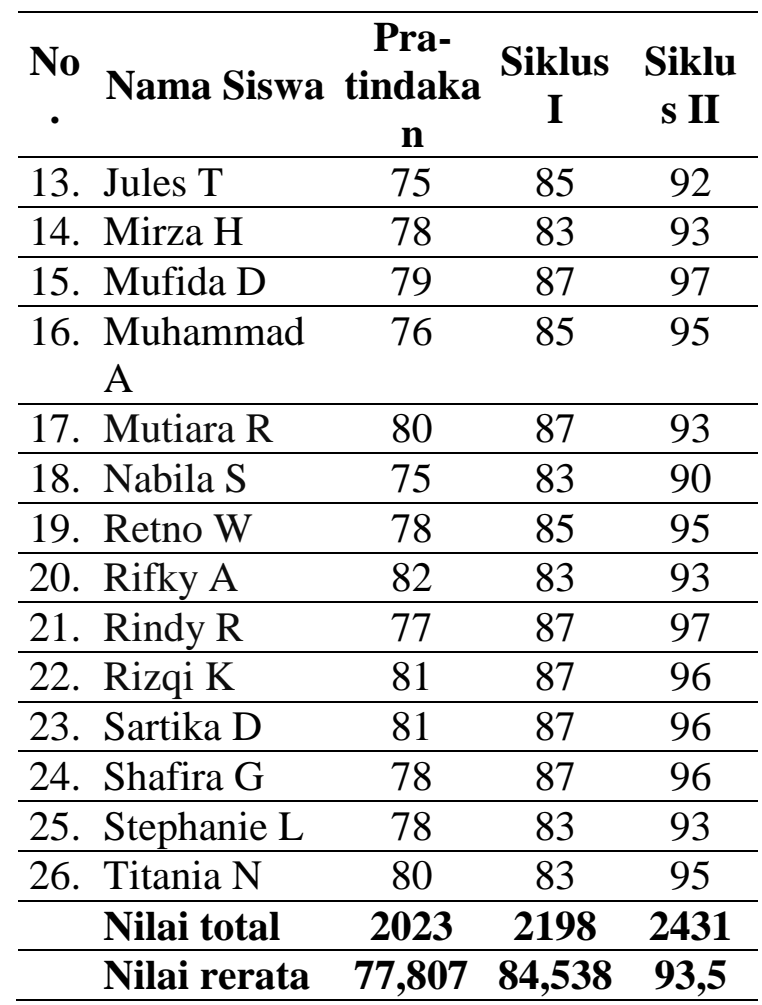

Peningkatan jumlah nilai rerata dari pratindakan, tindakan siklus I dan tindakan siklus II juga dapat disajikan dalam histogram di bawah ini.

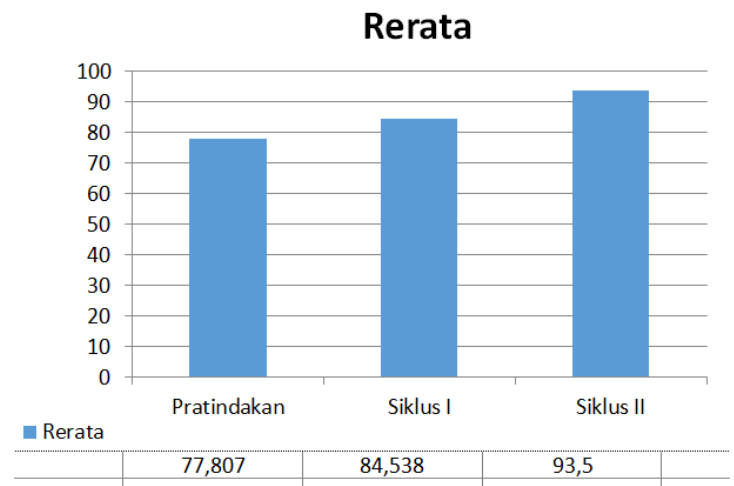

Grafik Peningkatan Nilai Rerata Tes

Kemampuan Berpikir Kritis

Dari histogram di atas dapat diketahui peningkatan nilai rerata dari pratindakan sampai siklus II. Pada pratindakan diperoleh nilai rerata 77,807 meningkat sebesar 6,731 menjadi 84,538 pada siklus I dan meningkat lagi sebesar 8,962 menjadi 93,5 pada siklus II.

Pencapaian kriteria keberhasilan siswa dapat dilihat dalam histogram berikut.

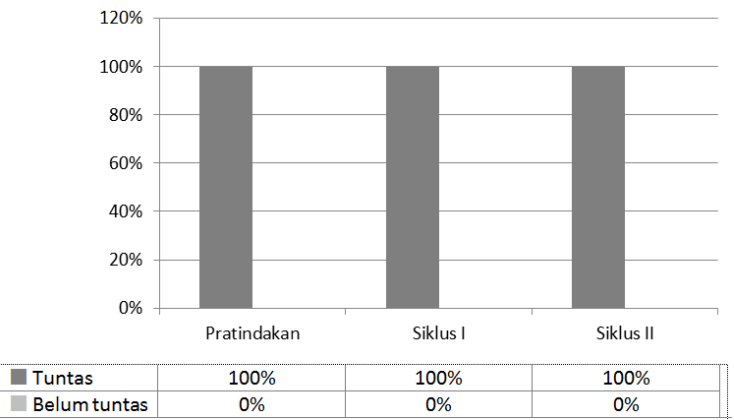

Grafik Peningkatan Pencapaian Keberhasilan Siswa

Dari histogram di atas dapat dilihat peningkatan pencapaian keberhasilan siswa dari pratindakan, siklus I dan siklus II. Siswa yang mencapai kriteria keberhasilan pada pratindakan rerata sebesar 77,807 dengan prosentase $100 \%$, meningkat menjadi 84,538 dengan prosentase $100 \%$ pada siklus I dan menjadi 93,5 dengan prosentase $100 \%$ pada siklus II.

\section{PEMBAHASAN}

Melihat hal tersebut, guru dan peneliti menyusun rencana perbaikan yang akan dilaksanakan dalam siklus II. Pada siklus II, hasil penelitian menunjukkan bahwa sebanyak 26 siswa dalam hitungan persen yaitu $100 \%$ dari 26 siswa sudah mencapai kriteria keberhasilan yang telah ditentukan, semakin meningkat diperoleh skor rerata yaitu 93,5. Dengan pemberian motivasi yang lebih baik, aktivitas siswa lebih meningkat dibanding dengan siklus I. Siswa sudah mulai terbiasa dan bisa terkondisikan ketika akan melakukan kerja kelompok dan diskusi bersama pasangannya. Siswa sudah berani dan tidak malu untuk mengemukakan pendapatanya. Aktivitas guru dan siswa sangat baik. suasana kelas sudah lebih terkondisikan karena masing-masing siswa cukup fokus dan antusias mengerjakan tugasnya. Pada saat diskusi kelas/presentasi, tidak lagi didominasi oleh beberapa siswa saja tetapi siswa lain mencoba mengemukakan komentar dan pendapatnya, sehingga kegiatan diskusi lebih hidup. Siswa sudah lebih memperhatikan, tidak lagi banyak bercanda dan mengobrol terutama yang 
dibarisan belakang. Untuk mendukung pernyataan tersebut Anita Lie (2010: 57) mengemukakan bahwa "keunggulan dari Think Pair Share adalah optimalisasi partisipasi siswa". Dengan keunggulan tersebut diharapkan dapat mengoptimalisasi partisipasi siswa untuk mengeluarkan pendapatnya, serta meningkatkan pembentukan pengetahuan yang utuh pada siswa.

Pada akhir siklus II, memang sudah tidak dijumpai siswa yang belum mencapai kriteria keberhasilan dari total seluruhnya 26 siswa. Tetapi masih ada beberapa siswa yang sebenarnya sulit berkonsentasi atau serius, bicara sendiri, malas, sibuk sendiri, acuh. Sehingga dibutuhkan waktu yang lebih lama dan berkesinambungan agar kemampuan berpikir kritis mereka meningkat. Pada dasarnya kriteria keberhasilan yang ditentukan telah tercapai karena sebanyak 100\% siswa kemampuan berpikir kritisnya sudah meningkat, namun demikian, peneliti dan guru sepakat untuk tetap memperhatikan beberapa siswa tersebut. Perlakuan-perlakuan yang akan diberikan guru yaitu: memberikan bimbingan lebih intensif, memberi motivasi untuk lebih percaya diri, dan melakukan pendekatan secara lebih mendalam. Peningkatan aktivitas guru dan siswa pada proses pembelajaran sangat mempengaruhi peningkatan kemampuan berpikir kritis siswa pada siklus I ke siklus II.

Berdasarkan observasi dan refleksi yang dilakukan guru dan peneliti, pelaksanaan pembelajaran PPKn dengan menggunakan model Think Pair Share telah sesuai dengan yang diharapkan. Sebagian besar siswa sudah menunjukkan keaktifannya dalam pembelajaran. Hasil penelitian juga menunjukkan bahwa siswa dapat melaksanakan pembelajaran dengan model Think Pair Share dengan baik sehingga berangsur-angsur kemampuan berpikir kritis siswa mengalami peningkatan. Dari uraian di atas dapat disimpulkan bahwa penggunaan model Think Pair Share untuk meningkatkan kemampuan berpikir kritis siswa kelas $\mathrm{X}$ IPS 1 SMA Negeri 6 Surakarta dalam pembelajaran PPKn dinilai berhasil.

\section{SIMPULAN}

Berdasarkan analisis terhadap data hasil penelitian dalam Penelitian Tindakan Kelas (PTK) di X IPS 1 SMA Negeri 6 Surakarta dengan penerapan model Thik Pair Share dengan melakukan tindakan yaitu perubahan dalam penyampaian materi pelajaran, siswa menganalisis permasalahan (think), pembentukan kelompok diskusi dengan mengubah pengelompokan siswa yang didasari dari prestasinya, siswa berpasangan untuk berdiskusi (pair), perwakilan kelompok siswa menyampaikan hasil diskusi di depan kelas (share). Langkah-langkah kegiatan tersebut dapat menguatkan kemampuan berpikir kritis siswa pada pembelajaran PPKn dengan materi pokok Hubungan Struktural dan Fungsional Pemerintah Pusat dan Daerah. Peningkatan ini terbukti pada pencapaian kemampuan berpikir kritis siswa dari pratindakan sebesar 100\%, meningkat menjadi $100 \%$ pada siklus I dan menjadi $100 \%$ pada siklus II, maka sudah tercapai nilai ketuntasan yaitu sebanyak $100 \%$ siswa mencapai taraf keberhasilan $100 \%$ ( $\geq$ skor $80 \%)$.

\section{DAFTAR RUJUKAN}

Agus Suprijono. 2013. Cooperatif Learning. Yogyakarta: Bima Bayu Atijah.

Anita Lie. 2010. Cooperative Learning. Jakarta: PT. Grasindo.

Asrori, dkk. 2009. Penelitian Tindakan Kelas (peningkatan Kompetensi Profesional Guru. Yogyakarta: Multi Pressindo.

Badan Standar Nasional Pendidikan. 2006. Standar Isi. Jakarta.

Chaedar Alwasilah. 2009. Contextual Teaching \& Learning. Bandung: MLC

Departemen Pendidikan Nasional. 2006. Kurikulum Tingkat Satuan Pendidikan. Jakarta: Dharma Bhakti. 
Eti Nurhayati. 2011. Psikologi Pendidikan Inovatif. Yogyakarta: Pustaka Pelajar.

Fahrudin Faiz. 2012. Thinking Skill (Pengantar Menuju Berpikir Kritis). Yogyakarta: SUKA-Press UIN Sunan Kalijaga.

Faturrohman dan Wuryandani, W. 2011. Pembelajaran Pkn Di Sekolah Dasar. Bantul: Nuha Litera.

Isjoni. 2012. Cooperative Learning: Efektivitas Pembelajaran Kelompok. Bandung: ALFABETA.

Ngalim Purwanto. 1992. Psikologi Pendidikan. Bandung: PT Remaja Rosdakarya.

Novia Agustina Widyaningrum. 2011. Perbedaan Hasil Belajar IPA pada Pembelajaran Kooperatif Tipe Think Pair Share (TPS) Dengan Pembelajaran Langsung Pada Tema Pencemaran Air Kelas VII SMP Negeri I Slogohimo. Skripsi. FIP: Universitas Negeri Yogyakarta. Tidak Diterbitkan.

Nurul Ma'rifah. 2014. Peningkatan Kemampuan Berpikir Kritis Siswa Melalui Model Cooperative Tipe Think Pair ShareDalam Pembelajaran Pkn Siswa Kelas V Sd Negeri 3 Puluhan Trucuk Klaten. Skripsi. FIP: Universitas Negeri Yogyakarta. Tidak Diterbitkan.

Puthut Hudi Purnomo. 2017. Penerapan Model Kooperatif TypeThink Pair Share (TPS) Untuk Meningkatkan Motivasi dan Hasil Belajar Siswa Pasif Dan Pada Kompetensi Pengenalan Sifat-Sifat Komponen Elektronika Aktif Siswa Kelas X Teknik Audio Video SMK N 1 Jiwan Madiun.Tesis. Teknologi Pendidikan : Universitas Sebelas Maret Surakarta. Tidak Diterbitkan.

Radno Harsanto. 2005. Melatih Anak Berfikir Analitis, Kritis, dan Kreatif. Semarang: Grasindo.

Saminanto. 2010. PTK(Penelitian Tindakan Kelas). Semarang: RaSAIL Media Group.
Suguhartono, dkk. 2007. Psikologi Pendidikan. Yogyakarta: UNY Press

Suharsimi Arikunto. 2010. Prosedur Penelitian: Suatu Pendekatan Praktik. Jakarta: PT Rineka Cipta.

Sunarso, dkk. Pendidikan Kewarganegaraan. 2006. Yogyakarta: UNY Press.

Supriya. 2009. Pendidikan IPS. Bandung: PT Reamaja Rosdakarya.

Suwarsih Madya. 1994. Panduan Penelitian Pendidikan. Yogyakarta : Lembaga Penelitian IKIP Yogyakarta. 